\title{
Socioeconomic Disparities of Facility-Based Childbirth in Indonesia
}

\author{
Agung Dwi Laksono ${ }^{1}$, Astridya Paramita ${ }^{1}$, *Ratna Dwi Wulandari ${ }^{2}$ \\ ${ }^{1}$ National Institute of Health Research and Development, the MOH of the Republic of \\ Indonesia. Jl. Percetakan Negara 29, Jakarta, Indonesia \\ ${ }^{2}$ Faculty of Public Health, Universitas Airlangga, Surabaya, Indonesia. Campus C Mulyorejo, \\ Surabaya, Indonesia \\ *Corresponding Author: \\ Ratna Dwi Wulandari. Email: ratna-d-w@ fkm.unair.ac.id
}

\begin{abstract}
Background: In Indonesia, only $74 \%$ of women give birth in health care facilities. This study was conducted to analyze the socioeconomic disparities of facilities-based childbirth in Indonesia.

Methods: The analysis in this study uses raw data from the 2017 Indonesia Demographic and Health Survey (IDHS). With stratification and multistage random sampling, 17,769 women aged 15-49 years with live births in the last 5 years were sampled. Data were analyzed using a Binary Logistic Regression test.

Results: Poorer women were 1.898 times more likely to use healthcare facilities for delivery than poorest women. Middle women were 2.669 times more likely to use healthcare facilities for delivery than poorest women. Richer women have 3.163 times more opportunities to use healthcare facilities for delivery than poorest women. The richest women were 6.566 times more likely to use healthcare facilities for delivery than the poorest women. Women who live in urban areas were 2.412 times more likely to use healthcare facilities for delivery than those who live in rural areas. Age, parity, level of education, ownership of health insurance, knowledge of the danger signs of pregnancy, and antenatal care, in maternity women the past five years significantly contribute to the utilization of healthcare facilities for delivery.

Conclusion: There was a significant disparity between socioeconomic in utilizing healthcare facilities for delivery in Indonesia. Women with better socioeconomic status have better possibilities for utilizing healthcare facilities for delivery.
\end{abstract}

Keywords: socioeconomic, wealth status, disparity analysis, facility-based childbirth

\section{BACKGROUND}

Maternal Mortality Rate (MMR) is still a priority health problem in the world, especially in several developing countries, including in Indonesia. MMR in Indonesia moves volatile. In the 2016 Annual Directorate of Family Health Report, MMR in Indonesia in 1994 reached 390 per 100,000 live births and tended to decrease to 228 in 2007. In 2012, the MMR increased again to 359 per 100,000 live births, and again dropped to 305 per 100,000 births lived in 2015. However, compared to countries in the South East Asia region, that number is still quite high (1).

Efforts to reduce maternal mortality need to begin with an in-depth study of the risk factors for complex maternal mortality. The factors causing MMR are divided into 2 groups of factors namely direct causes and indirect causes. Direct causative factors include uterine complications during the phases of pregnancy, childbirth and the puerperium (2). Indirect factors or intermediate factors include health service factors such as services during pregnancy, childbirth, and childbirth 
(3)(4); education factor (5)(6)(7); economic factors (8)(9), and social factors, which are related to public trust in non-health workers, such as traditional birth attendants, as birth assistants $(10)(11)(12)$.

The 2017 Indonesian Demographic Data Survey (IDHS) reports that 74\% of women deliver in health care facilities in Indonesia. There were $42 \%$ of women who gave birth at firstlevel health service facilities, which included health centers and their networks, clinics, and practices of health workers. While those delivering to advanced referral service facilities or hospitals are $32 \%(13)$.

One of the basic principles of every health care system that must be pursued is equal access to health care facilities. Each individual must be given the opportunity to access health services in accordance with their health requirements, the poor are no exception (14). The government must be present to ensure equal access by reducing disparities in utilization of health service facilities (15). Disparity in the utilization of health service facilities in Indonesia still exists today. Disparities in utilization of health service facilities generally occur in the urban-rural category and between regions (16)(17)(18).

Based on the background, this article was compiled to analyze Socioeconomic Disparities of Facility-Based Childbirth in Indonesia. The analysis in this study is useful for policymakers in the field of maternal health to formulate more detailed policies according to the targets identified in the study results. This step is necessary to ensure more equal delivery of labor.

\section{MATERIALS AND METHODS}

\section{Data Source.}

Secondary data from the 2017 Indonesian Demographic Data Survey (IDHS) was used as analysis material in this study. The IDHS was part of the International Demographic and Health Survey (DHS) program conducted by the Inner City Fund (ICF). The 2017 IDHS was carried out by the Central Statistics Agency (BPS), in collaboration with the National Population and Family Planning Board (BKKBN) and the Ministry of Health. The 2017 IDHS sample was determined through stratification and multistage random sampling. The unit of analysis in this study was women aged 15-49 years old who had given birth in the last 5 years. The sample size of the 2017 IDHS used in this analysis was 17,769 women.

\section{Procedure.}

The 2017 IDHS has passed ethical tests from the National Institute of Health Research and Development of the Indonesian Ministry of Health. The respondents' identities have all been deleted from the dataset. Respondents have provided written approval for their involvement in the study. The use of the 2017 IDHS data for this study has received permission from ICF International through its website: https://dhsprogram.com/data/new-user-registration.cfm.

\section{Data Analysis.}

Socioeconomic was the wealth status of respondents compiled based on the index of goods ownership quintile stated by the respondent. The five categories were poorest (quintile 1), poorer (quintile 2), middle (quintile 3), richer (quintile 4), and richest (quintile 5). Delivery at a health service facility was a delivery at a health center, clinic or maternity hospital, the practice of health workers and hospitals (19). The 2017 IDHS data was obtained through a structured questionnaire. Variables analyzed included childbirth facility, wealth status, place of residence, age, education 
level, work status, marital status, parity, health insurance, the autonomy of family finances, the autonomy of health, knowledge of pregnancy, knowledge of delivery, and antenatal care.

Statistical analysis using Chi-Square was carried out for dichotomous variables and t-test for continuous variables. This statistical analysis was conducted to assess whether there were differences in childbirth facility that were statistically significant between the category of wealth status. Estimates were performed using Binary Logistic Regression because of the nature of the dependent variable. All statistical analyses were carried out using SPSS 19 software.

\section{RESULTS}

Researchers conducted a co-linearity test before carrying out a binary logistic regression test. Table 1 informs the results of the co-linearity test which shows that there is no co-linearity between the dependent and independent variables. Table 1 informs that the tolerance value of all variables is greater than 0.10 . While the VIF value for all variables is less than 10.00 . Then referring to the basis of decision making in the multicollinearity test it can be concluded that there were no symptoms of multicollinearity in the regression model.

Table 1. Results for a co-linearity test of Facility-based Childbirth in Indonesia

\begin{tabular}{lcc}
\hline \multirow{2}{*}{ Variables } & \multicolumn{2}{c}{ Collinearity Statistics } \\
\cline { 2 - 3 } & Tolerance & VIF \\
\hline Wealth status & 0.611 & 1.637 \\
Place of Residence & 0.765 & 1.307 \\
Age & 0.586 & 1.705 \\
Education level & 0.723 & 1.383 \\
Work status & 0.935 & 1.070 \\
Marital status & 0.814 & 1.228 \\
Parity & 0.539 & 1.856 \\
Health insurance & 0.962 & 1.040 \\
The autonomy of family finances & 0.797 & 1.255 \\
The autonomy of health & 0.719 & 1.392 \\
Know the dangers of the pregnancy & 0.899 & 1.113 \\
Antenatal care & 0.881 & 1.135 \\
\hline
\end{tabular}

*Dependent Variable: Childbirth Services

Table 2 shows that there are differences between women who use healthcare facilities for delivery based on wealth status for all characteristics observed that are statistically significant, except autonomy for family financial. Table 2 informs that in all wealth categories the status of women who use healthcare facilities for delivery is more dominant than those who deliver at nonhealthcare facilities. 
Table 2. Descriptive Statistics of Facility-Based Childbirth by Socioeconomic in Indonesia

\begin{tabular}{|c|c|c|c|c|c|c|c|}
\hline \multirow{2}{*}{ Characteristics } & \multicolumn{5}{|c|}{ Wealth Status } & \multirow{2}{*}{ All } & \multirow{2}{*}{$\mathbf{P}$} \\
\hline & Poorest & Poorer & Middle & Richer & Richest & & \\
\hline Place of Delivery & & & & & & & 0.000 \\
\hline - Nonhealthcare Facilities & $2683(54.39 \%)$ & $1033(29.77 \%)$ & $629(19.37 \%)$ & $441(14.13 \%)$ & $184(6.14 \%)$ & $4970(27.97 \%)$ & \\
\hline - Healthcare Facilities & $2250(45.61 \%)$ & $2437(70.23 \%)$ & $2619(80.63 \%)$ & $2681(85.87 \%)$ & $2812(93.86 \%)$ & $12799(72.03 \%)$ & \\
\hline Place of Residence & & & & & & & 0.000 \\
\hline - Urban & $832(16.86 \%)$ & $1387(39.97 \%)$ & $1836(56.53 \%)$ & $2176(69.70 \%)$ & $2492(83.18 \%)$ & $8723(49.09 \%)$ & \\
\hline - Rural & $4101(83.13 \%)$ & $2083(60.03 \%)$ & $1412(43.47 \%)$ & $946(30.30 \%)$ & $504(16.82 \%)$ & $9046(50.91 \%)$ & \\
\hline Age (mean) & $4933(30.31)$ & $3470(30.31)$ & $3248(30.78)$ & $3122(31.11)$ & $2996(32.19)$ & $17769(30.85)$ & 0.000 \\
\hline Education level & & & & & & & 0.000 \\
\hline - No education (ref.) & $217(4.40 \%)$ & $32(0.92 \%)$ & $12(0.37 \%)$ & $5(0.16 \%)$ & $3(0.10 \%)$ & $269(1.51 \%)$ & \\
\hline - Primary & $2201(44.62 \%)$ & $1004(28.93 \%)$ & $693(21.34 \%)$ & $380(12.17 \%)$ & $153(5.11 \%)$ & $4431(24.94 \%)$ & \\
\hline - Secondary & $2255(45.71 \%)$ & $2066(59.54 \%)$ & $2123(65.36 \%)$ & $2019(64.67 \%)$ & $1416(47.26 \%)$ & $9879(55.60 \%)$ & \\
\hline - Higher & $260(5.27 \%)$ & $368(10.61 \%)$ & $420(12.93 \%)$ & $718(23.00 \%)$ & $1424(47.53 \%)$ & $3190(17.95 \%)$ & \\
\hline Work status & & & & & & & 0.000 \\
\hline - No work (ref.) & $2781(56.38 \%)$ & $2080(59.94 \%)$ & $1824(56.16 \%)$ & $1551(49.68 \%)$ & $1248(41.66 \%)$ & $9484(53.37 \%)$ & \\
\hline - Work & $2152(43.62 \%)$ & $1390(40.06 \%)$ & $1424(43.84 \%)$ & $1571(50.32 \%)$ & $1748(58.34)$ & $8285(46.63 \%)$ & \\
\hline Marital status & & & & & & & 0.000 \\
\hline - Never married (ref.) & $23(0.47 \%)$ & $2(0.06 \%)$ & $3(0.09 \%)$ & $1(0.03 \%)$ & $0(0.00 \%)$ & $29(0.16 \%)$ & \\
\hline - Married/Living with Partner & $4724(95.76 \%)$ & $3361(96.86 \%)$ & $3152(97.04 \%)$ & $3034(97.18 \%)$ & $2941(98.16 \%)$ & $17212(96.87 \%)$ & \\
\hline - Divorced/Widowed & $186(3.77 \%)$ & $107(3.08 \%)$ & $93(2.86 \%)$ & $87(2.79 \%)$ & $55(1.84 \%)$ & $528(2.97 \%)$ & \\
\hline Parity (mean) & $4933(2.95)$ & $3470(2.45)$ & $3248(2.32)$ & $3122(2.24)$ & $2996(2.31)$ & $17769(2.51)$ & 0.000 \\
\hline Health insurance & & & & & & & 0.000 \\
\hline - No (ref.) & $2037(41.29 \%)$ & $1469(42.33 \%)$ & $1321(40.67 \%)$ & $1137(36.42 \%)$ & $737(24.60 \%)$ & $6701(37.71 \%)$ & \\
\hline - Yes & $2896(58.71 \%)$ & $2001(57.67 \%)$ & $1927(59.33 \%)$ & $1985(63.58 \%)$ & $2259(75.40 \%)$ & $11068(62.29 \%)$ & \\
\hline The autonomy of family finances & & & & & & & 0.058 \\
\hline - No (ref.) & $1312(26.60 \%)$ & $933(26.89 \%)$ & $850(26.17 \%)$ & $798(25.56 \%)$ & $718(23.97 \%)$ & $4611(25.95 \%)$ & \\
\hline - Yes & $3621(73.40 \%)$ & $2537(73.11 \%)$ & $2398(73.83 \%)$ & $2324(74.44 \%)$ & $2278(76.03 \%)$ & $13158(74.05 \%)$ & \\
\hline The autonomy of health & & & & & & & 0.000 \\
\hline - No (ref.) & $754(15.28 \%)$ & $496(14.29 \%)$ & $425(13.08 \%)$ & $408(13.07 \%)$ & $335(11.18 \%)$ & $2418(13.61 \%)$ & \\
\hline - Yes & $4179(84.72 \%)$ & $2974(85.71 \%)$ & $2823(86.92 \%)$ & $2714(86.93 \%)$ & $2661(88.82 \%)$ & $15351(86.39 \%)$ & \\
\hline Know the danger signs of the pregnancy & & & & & & & 0.000 \\
\hline - No (ref.) & $2544(51.57 \%)$ & $1358(39.14 \%)$ & $1075(33.10 \%)$ & $824(26.39 \%)$ & $563(18.79 \%)$ & $6364(35.82 \%)$ & \\
\hline - Yes & $2389(48.43 \%)$ & $2112(60.86 \%)$ & $2173(66.90 \%)$ & $2298(73.61 \%)$ & $2433(81.21 \%)$ & $11405(64.18 \%)$ & \\
\hline Antenatal care & & & & & & & 0.000 \\
\hline$-<4$ times (ref.) & $1774(35.96 \%)$ & $807(23.26 \%)$ & $618(19.03 \%)$ & $533(17.07 \%)$ & $507(16.92 \%)$ & $4239(23.86 \%)$ & \\
\hline$-\geq 4$ times & $3159(64.04 \%)$ & $2663(76.74 \%)$ & $2630(80.97 \%)$ & $2589(82.93 \%)$ & $2489(83.08 \%)$ & $13530(76.14 \%)$ & \\
\hline
\end{tabular}

Note: Chi-Square test was used for dichotomous variables; T-test for continuous variables. 
Table 2 informs that the poorest women predominantly live in rural areas. While the richest women are more dominant in urban areas. Table 2 shows that the average richest woman is slightly older than other wealth status categories. Indonesian women who gave birth in the last five years were also dominated by those who had secondary education in all wealth status categories.

Table 2 informs that Indonesian woman who gave birth in the last five years were dominated by those who did not work in all categories of wealth status, except for the richest women who were more dominated by women who worked. As for the Marital status category, women are dominated by married / living with partner status in all wealth status categories.

Table 2 shows that in all wealth categories the status of Indonesian women who gave birth in the last five years in urban areas had a parity of between 2-3. In the category of health insurance ownership, Indonesian women who gave birth in the last five years were dominated by those covered by health insurance in all wealth status categories.

The autonomy of the family financial category is dominated by women who have autonomy in all wealth status categories, but the autonomy of the family finances category is not statistically significant. While the autonomy of the health category is dominated by women who have autonomy in all wealth status categories, and this autonomy of the health category is statistically significant.

Table 2 shows Indonesian women who gave birth in the last five years in all wealth status categories dominated by those who knew about the danger signs of the pregnancy, except the poorest women. Indonesian women who gave birth in the last five years in all wealth status categories were dominated by women who had antenatal care more than 4 times.

Table 3. Binary Logistic Regression of The Use of Healthcare Facilities for Delivery in Indonesia $(\mathrm{n}=17,769)$.

\begin{tabular}{lccc}
\hline \multirow{2}{*}{\multicolumn{1}{c}{ Predictor }} & \multicolumn{3}{c}{ Healthcare Facilities } \\
\cline { 2 - 4 } & OR & Lower Bound & Upper Bound \\
\hline Wealth status: poorer & $* * * 1.898$ & 1.719 & \\
Wealth status: middle & $* * * 2.669$ & 2.383 & 2.095 \\
Wealth status: richer & $* * * 3.163$ & 2.779 & 3.689 \\
Wealth status: richest & $* * * 6.566$ & 5.495 & 7.847 \\
Place of Residence: Urban & $* * * 2.412$ & 2.214 & 2.627 \\
Age & $* * * 1.039$ & 1.031 & 1.047 \\
Education level: Primary & $* 1.375$ & 1.025 & 1.845 \\
Education level: Secondary & $* * * 1.875$ & 1.396 & 2.517 \\
Education level: Tertiary & $* * * 1.720$ & 1.257 & 2.354 \\
Work status: work & 0.949 & 0.877 & 1.027 \\
Marital status: Never Married & 0.540 & 0.237 & 1.229 \\
Marital status: Married/Living with Partner & 0.559 & 0.241 & 1.295 \\
Parity & $* * * 0.789$ & 0.764 & 0.815 \\
Health insurance: Yes & $* * * 1.438$ & 1.332 & 1.553 \\
The autonomy of health: Yes & 1.016 & 0.901 & 1.145 \\
Know the danger signs of pregnancy: Yes & $* * * 1.513$ & 1.400 & 1.635 \\
Antenatal care: $\geq 4$ times & $* * * 1.734$ & 1.590 & 1.890 \\
\hline Note: $*$ p $<.05 ; * *$ p $<0.01 ; * * p<0.001$ & & & \\
\hline
\end{tabular}

Note: $* \mathrm{p}<0.05 ; * * \mathrm{p}<0.01 ; * * * \mathrm{p}<0.001$. 
Table 3 displays the results of the binary logistic regression test to illustrate the disparity in the utilization of healthcare facilities for delivery between socioeconomic status in Indonesia. As a reference, the chosen category is "nonhealthcare facilities". Table 3 shows the significant differences between all socioeconomic status in utilizing healthcare facilities for delivery.

Table 3 informs that poorer women are 1.898 times more likely to use healthcare facilities for delivery than poorest women (OR 1.898; 95\% CI 1.719-2.095). Middle women are 2.669 times more likely to use healthcare facilities for delivery than poorest women (OR 2.669; 95\% CI 2.3832.989). Richer women were 3.163 times more likely to use healthcare facilities for delivery than poorest women (OR 3.163; 95\% CI 2.779-3.601). Richest women have the possibility of 6.566 times more utilizing healthcare facilities for delivery than poorest women (OR 6.566; $95 \% \mathrm{CI}$ 5.495-7.847).

Table 3 shows that women who live in urban areas are 2.412 times more likely to use healthcare facilities for delivery than those living in rural areas (OR 2.412; 95\% CI 2.214-2.627). Table 3 informs that age and parity in women significantly contribute to the utilization of healthcare facilities for delivery.

Table 3 shows that women with tertiary education levels were 1.720 times more likely to use healthcare facilities for delivery than those without education (OR 1.720; 95\% CI 1.2572.354). While work status and marital status did not show a significant effect.

Table 3 informs that women who are covered by health insurance are 1.438 times more likely to use healthcare facilities for delivery than women who do not have health insurance (OR $1.438 ; 95 \%$ CI 1.332-1.553). While the autonomy of the health category does not have a significant effect on the utilization of healthcare facilities for delivery.

Table 3 shows that women who know the danger signs of pregnancy are 1.513 times more likely to utilize healthcare facilities for delivery than women who do not know the danger signs of pregnancy (OR $1.513 ; 95 \%$ CI 1.400-1.635). While women who did antenatal care $\geq 4$ times were 1.734 times more likely to use healthcare facilities for delivery than women who did antenatal care $<4$ times (OR 1.735; 95\% CI 1.590-1.890).

\section{DISCUSSION}

The results showed that in Indonesia there is still a socioeconomic disparity in the utilization of health care facilities for childbirth. The richer a woman is, the more she chooses to deliver in a health care facility. The poorest women have the lowest utilization of health care facilities for childbirth. This is in line with the results of recent research in several countries that take the theme of socioeconomic disparity, namely in Zimbabwe (20), China (21), Spain (22), Germany (23), and USA (24)(25)(26).

The results found that women with tertiary education more utilized healthcare facilities for delivery than those who did not attend school. In general, poor people have the characteristics of lack of education, so the level of education is directly proportional to socioeconomic. Similar results were also found in studies in several countries (27)(28)(29), including in Nigeria who found that not only low educational status but also beliefs about illness, significantly affected the low utilization of health services in rural communities (30).

Women who have health insurance are proven to use healthcare facilities for delivery more than those who do not have health insurance. The results of this study are in line with several studies that take the same theme to evaluate the impact of health insurance on the utilization of health care facilities. Health insurance is the most common weapon that is effective for improving healthcare utilization (31) (32)(33). 
In the Indonesian context, the government has issued a policy to subsidize membership contribution assistance for the poor in the National Health Insurance (34). The results of this study indicate that the policy has not yet had a satisfying impact. Utilization of health care facilities for childbirth among the poorest women still has the lowest coverage.

The Indonesian government's policy to subsidize membership contribution assistance for the poor in the National Health Insurance is appropriate (35)(9). But it needs to be coupled with more intense socialization policies, so that poor women know their rights, and want to take advantage of the benefits package offered in the National Health Insurance for delivery.

\section{CONCLUSIONS}

Based on the results of the study it can be concluded that there is a significant disparity between socioeconomic in utilizing healthcare facilities for delivery in Indonesia. Women with better socioeconomic have better possibilities to utilize healthcare facilities for delivery.

\section{Acknowledgments}

The author would like to thank the Inner City Fund for allowing the use of the 2017 IDHS.

\section{Conflict of Interest}

The authors declare no conflict of interest, financial or otherwise.

\section{REFERENCES}

1. Directorate of Family Health-The Indonesia MOH. The 2016 Directorate of Family Health Annual Report [Internet]. Jakarta; 2016. Available from: http://kesga.kemkes.go.id/images/pedoman/Laptah TA 2016 Dit Kesga.pdf

2. National Institute of Health Research and Development of Ministry of Health of the Republic of Indonesia, United Nations Population Fund. Access and Quality Disparities; Determinant Study of Maternal Death in Five Region of Indonesia [Internet]. Jakarta; 2012. Available from: https://indonesia.unfpa.org/sites/default/files/pub-pdf/Final Buku Kajian Balitbang_OK.pdf

3. Nurrizka RH, Wahyono TYM. Disparity of Maternal Mortality in Indonesia: Ecological Study with Spatial Analysis. Media Kesehat Masy Indones. 2018;14(2):119-27.

4. Hamal M, Dieleman M, De Brouwere V, Buning TC. How do accountability problems lead to maternal health inequities? A review of qualitative literature from Indian public sector. Public Health Rev. 2018;39(1):Article number 9.

5. Sisay MM, Geremew TT, Demlie YW, Alem AT, Beyene DK, Melak MF, et al. Spatial patterns and determinants of postnatal care use in Ethiopia: Findings from the 2016 demographic and health survey. BMJ Open. 2019;9(6):Article number e025066.

6. Geleto A, Chojenta C, Musa A, Loxton D. WOMEN's Knowledge of Obstetric Danger signs in Ethiopia (WOMEN's KODE):a systematic review and meta-analysis 11 Medical and Health Sciences 1117 Public Health and Health Services. Syst Rev. 2019;8(1):Article number 63.

7. Jungari S, Paswan B. What he knows about her and how it affects her? Husband's knowledge of pregnancy complications and maternal health care utilization among tribal population in Maharashtra, India. BMC Pregnancy Childbirth. 2019;19(1):Article number 70.

8. Zalvand R, Yaseri M, Mosadeghrad AM, Tajvar M. Determinants of maternal mortality in 
iran 1990-2015: A longitudinal study. Tehran Univ Med J. 2019;77(2):82-91.

9. Mulyanto J, Kringos DS, Kunst AE. Socioeconomic inequalities in healthcare utilisation in Indonesia: a comprehensive survey-based overview. BMJ Open. 2019;9(7):Article number e026164.

10. Laksono AD, Soerachman R, Angkasawati TJ. Case Study of Muyu Ethnic's Maternal Health in Mindiptara District-Boven Digoel (Studi Kasus Kesehatan Maternal Suku Muyu di Distrik Mindiptana, Kabupaten Boven Digoel). J Reprod Heal. 2016;07/03:145-55.

11. Chukwuma A, Mbachu C, Cohen J, Bossert T, McConnell M. "Once the delivery is done, they have finished": A qualitative study of perspectives on postnatal care referrals by traditional birth attendants in Ebonyi state, Nigeria. BMC Pregnancy Childbirth. 2017;17(1):Article number 429.

12. MacDonald T, Jackson S, Charles M-C, Periel M, Jean-Baptiste M-V, Salomon A, et al. The fourth delay and community-driven solutions to reduce maternal mortality in rural Haiti: A community-based action research study. BMC Pregnancy Childbirth. 2018;18(1):Article number 254.

13. National Population and Family Planning Board, Statistics Indonesia, Ministry of Health, The DHS Program. Indonesia Demographic and Health Survey 2017 [Internet]. Jakarta; 2018. Available from: https://www.dhsprogram.com/pubs/pdf/FR342/FR342.pdf

14. Tzeng H-M, Okpalauwaekwe U, Yin C-Y, Jansen SL, Feng C, Barker A. Do patients' demographic characteristics affect their perceptions of self-care actions to find safe and decent care? Appl Nurs Res. 2018;43:24-9.

15. Li J, Shi L, Liang H, Ding G, Xu L. Urban-rural disparities in health care utilization among Chinese adults from 1993 to 2011. BMC Health Serv Res. 2018;18(102):1-9.

16. Laksono AD, Wulandari RD, Soedirham O. Urban and Rural Disparities in Hospital Utilization among Indonesian Adults. Iran J Public Health [Internet]. 2019;48(2):247-55. Available from: http://ijph.tums.ac.ir/index.php/ijph/article/view/16143

17. Wulandari RD, Laksono AD. Urban-Rural Disparities in The Utilization of Primary Health Care Center Among Elderly in East Java, Indonesia. J Adm Kesehat Indones. 2019;7(2):in press.

18. Laksono AD, Wulandari RD, Soedirham O. Regional Disparities of Health Center Utilization in Rural Indonesia. Malaysian J Public Heal Med. 2019;19(1).

19. Ministry of Health of the Republic of Indonesia. Republic of Indonesia Minister of Health Regulation Number 99/2015 concerning Health Services at National Health Insurance. Indonesia; 2015.

20. Tapera O, Kadzatsa W, Nyakabau AM, Mavhu W, Dreyer G, Stray-Pedersen B, et al. Sociodemographic inequities in cervical cancer screening, treatment and care amongst women aged at least 25 years: Evidence from surveys in Harare, Zimbabwe. BMC Public Health. 2019;19(1):Article number 428.

21. Song S, Yuan B, Zhang L, Cheng G, Zhu W, Hou Z, et al. Increased inequalities in health resource and access to health care in rural China. Int $\mathbf{J}$ Environ Res Public Health. 2019;16(1):Article number 49.

22. Pérez-Ardanaz B, Morales-Asencio JM, García-Piñero JM, Lupiáñez-Pérez I, Morales-Gil IM, Kaknani-Uttumchandani S. Socioeconomic Status and Health Services Utilization for Children With Complex Chronic Conditions Liable to Receive Nurse-Led Services: A Cross-Sectional Study. J Nurs Scholarsh. 2019;in press.

23. Schröder SL, Fink A, Richter M. Socioeconomic differences in experiences with treatment 
of coronary heart disease: A qualitative study from the perspective of elderly patients. BMJ Open. 2018;8(11):Article number e024151.

24. Arroyo NS, White RS, Gaber-Baylis LK, La M, Fisher AD, Samaru M. Racial/Ethnic and Socioeconomic Disparities in Total Knee Arthroplasty 30- and 90-Day Readmissions: A Multi-Payer and Multistate Analysis, 2007-2014. Popul Health Manag. 2019;22(2):175-85.

25. Makar M, Worple E, Dove J, Hunsinger M, Arora T, Oxenberg J, et al. Disparities in care: Impact of socioeconomic factors on pancreatic surgery: Exploring the national cancer database. Am Surg. 2019;85(4):327-34.

26. Kirshenbaum EJ, Doshi C, Dornbier R, Blackwell RH, Bajic P, Gupta GN, et al. Socioeconomic disparities in the acute management of stone disease in the United States. J Endourol. 2019;33(2):167-72.

27. Ozumba BC, Onyeneho NG, Chalupowski M, Subramanian SV. Inequities in Access to Maternal Health Care in Enugu State: Implications for Universal Health Coverage to Meet Vision 2030 in Nigeria. Int Q Community Health Educ. 2019;39(3):163-73.

28. Oh JH. Educational expansion and health disparities in Ethiopia, 2005-2016. Soc Sci Med. 2019;235:Article number 112316.

29. Yaya S, Bishwajit G, Gunawardena N. Socioeconomic factors associated with choice of delivery place among mothers: A population-based cross-sectional study in Guinea-Bissau. BMJ Glob Heal. 2019;4(2):Article number e001341.

30. Mbada C, Olawuyi A, Oyewole OO, Odole AC, Ogundele AO, Fatoye F. Characteristics and determinants of community physiotherapy utilization and supply. BMC Health Serv Res. 2019;19(1):Article number 168.

31. Kemmick Pintor J, Chen J, Alcalá HE, Langellier BA, McKenna RM, Roby DH, et al. Insurance Coverage and Utilization Improve for Latino Youth but Disparities by Heritage Group Persist Following the ACA. Med Care. 2018;56(11):927-33.

32. Miraldo M, Propper C, Williams RI. The impact of publicly subsidised health insurance on access, behavioural risk factors and disease management. Soc Sci Med. 2018;217:135-51.

33. Müllerschön J, Koschollek C, Santos-Hövener C, Kuehne A, Müller-Nordhorn J, Bremer V. Impact of health insurance status among migrants from sub-Saharan Africa on access to health care and HIV testing in Germany: A participatory cross-sectional survey 11 Medical and Health Sciences 1117 Public Health and Health Services 11 Medical and Healt. BMC Int Health Hum Rights. 2019;19(1).

34. Agustina R, Dartanto T, Sitompul R, Susiloretni KA, Suparmi, Achadi EL, et al. Universal health coverage in Indonesia: concept, progress, and challenges. Lancet. 2019;393(10166):75-102.

35. Madyaningrum E, Chuang Y-C, Chuang K-Y. Factors associated with the use of outpatient services among the elderly in Indonesia. BMC Health Serv Res. 2018;18(1):707. 